\title{
E-Government Strategy and Plans in Jordan
}

\author{
Yousef Kh. Majdalawi, Tamara Almarabeh, Hiba Mohammad, Wala Quteshate \\ Department of Computer Information Systems, King Abdullah II School for Information Technology, The \\ University of Jordan, Amman, Jordan \\ Email: ymajdal@ju.edu.jo, t.almaraabeh@ju.edu.jo, h.khadrawi@ju.edu.jo, w.qutechate@ju.edu.jo
}

Received 30 March 2015; accepted 23 April 2015; published 24 April 2015

Copyright (C) 2015 by authors and Scientific Research Publishing Inc.

This work is licensed under the Creative Commons Attribution International License (CC BY).

http://creativecommons.org/licenses/by/4.0/

(c) (i) Open Access

\begin{abstract}
Life is being developed every day in all of the life aspects. One of the major developing aspects is information technology (IT), and communication technology which makes life easier, faster, and more connected. ICT is evolving fast in Jordan and offering the government to deliver multiple delivery services with different characteristics among E-government services. The Jordanian government has invested heavily in E-government initiatives for the last 10 years to transform from traditional service delivery to more effective and efficient service to deliver high-quality customer-centric and performance-driven services to E-government stakeholders. However the global rank of E-government readiness as well as regional rank of Jordan is still in low rank according to the global countries but it is still quite according to the Arab countries. This research provides a trend analysis to find the trends (positive or negative) in the UN E-government indicators in Jordan and provides an overview to the E-government in Jordan where the researchers analyze the development of E-government in Jordan by introducing a general framework for the E-government through discussing the past, present status and the future plans for E-government in Jordan to get better service to their recipients and to improve overall progress of Jordan achievements compared with regional and global countries.
\end{abstract}

\section{Keywords}

Jordan, Readiness, ICT, EGDI, E-Government

\section{Introduction}

Governments play a major roles in societies as the administration of government functions and the facilitation of providing services to citizens and civil society institutions through their project in a convenient an efficient way [1]. The improvements in information and communication technologies (ICTs) increase the number of people in both private and public sectors, who benefit from a wide range of services through the Internet and web. The 
governments try to use ICT as a way to improve their interactions with citizens through providing them with real time access to information and many e-services via the Internet which led to a phenomenon called electronic government or E-government.

Some researchers defined E-government as the use of ICT to transform government institutions and processes into IT-based enablers [2]-[4]. Others define E-government is the implementation of ICT to improve all governmental transactions with all stakeholders' categories (within government, between government agencies, businesses and citizens) [5]-[8]. According to (Bose [9]) E-government is the application of ICT to the innovation in, and improvement of government services.

The United Nations defined E-government as the use of Information and Communication Technology (ICT) and its application by the government for the provision of information and public services to the people [10].

Other researchers added E-government definition with purpose to support good governance in the government organization for example, Jeffry (2008) [11] defined E-government as a continuous innovations in the delivery of services, citizen participation, and governance through the transformation of external and internal relationships by the use of information technology, especially the internet.

E-government added new concepts such as: transparency, accountability, citizen participation in the evaluation of government performance [12]. As one of the developing countries, the Jordanian government has made an initial effort to define E-government as "the ability to submit governmental transactions on-line and make payments electronical where they are required" [13].

Generally, E-government is considered as a new and emerging area of interest in the field of E-business that employs ICTs to enhance the access to and delivery of government information and services to citizens, businesses, government employees, and other agencies [14] [15].

Jordanian government is offering multiple business and technical services to support interaction between government entities and their customers through E-government. Government program in Jordan was launched by his Majesty King Abdullah II to achieve greater efficiency in government performance by raising the level of service delivery to clients and investors from all segments of society easily, quickly, accurately and efficiently and to become a new type of performance of government employees and government transactions [12]. E-government in Jordan is dedicated to delivering services to people across society, irrespective of location, economic status, education or ICT ability.

This paper analyzes the trends (positive or negative) in the UN E-government indicators in Jordan which can help in the development of proposals, plans and strategies to improve the level of E-government in Jordan.

This paper is organized as follows: Section 2 shows literature review of E-government program in Jordan, its vision and mission. Section 3 discusses E-government Readiness in Jordan through United Nations Readiness reports. Section 4 addresses the challenges and opportunities with different factors for achieving the success for E-government projects, especially in Jordan. Section 5 explains the new strategy of E-government in Jordan. Finally the conclusion is drawn in Section 6.

\section{Literature Review of E-Government Program in Jordan}

His Majesty King Abdullah II, king of Hashemite kingdom of Jordan, announced in 1999, that more efforts should be done to focus on the information technology (IT) industry, as a main generator of economic growth, and integrate it to the daily lives of Jordanians. As a result, and to insure this vision comes true, national E-government initiatives were conducted to cope with the governmental processes, and to make information available to the people on the internet. At that time, the ministry of Post and Communications (MOPC), which changed later to MOICT, was in charge of these initiatives, and it had to establish new departments and staff, just for the purpose of IT issues including organizational restructuring and legal reform. However, the transformation process of the ministry needed highly skilled IT human resources, in addition to high technology resources.

In 2001, (MOPC) transformed into the Ministry of Information and Communications Technology (MOICT) and launched its E-government Program, also a new office was established called Program Management office (PMO) to assist the Ministry, and to coordinate E-government projects, in addition to study the benefits that can be available to the people, and raise their perception to the e-services in the same time.

Two researchers, Michael Blakemore and Roderic Dutton, in their research "E-government, e-Society and Jordan: Strategy, theory, practice, and assessment”, analyzed the strategy statements of E-government project implementations in several countries and summarized the expectations' of these nations from implementing an 
E-government project such as [16]:

1. Government to citizen (G2C), with the citizen being treated as customer not administrative objects:

- Receiving services that are citizen-, not agency-focused

- Disintermediation of civil service staff-means making services delivered directly to the citizens.

- Intelligent authentication like smartcard

- Providing an access to the governmental information.

- Being provided with access to the physical ICT infrastructure

- Being made "more equal” (reductions in digital and other divides)

- Enhancing trust and make it stronger.

All of these expectations can be included in Jordan in transports Registration, insurance, unemployed compensation, collecting income taxes, leaving work programs (retiring), licensing, and welfare benefits.

2. Government to Government (G2G), involving good governance and a well-governed society, where this kind of relationship between G2G can be found in the United States, like state to local government, integrated justice system, or state to federal government.

- Reducing the fractured nature of individual department and agencies, and moving towards "joined-up" government. Like join all the governmental departments together, and make related data to be transferred between them easily, and safely. This will reduce time consuming, and makes the progress more effective.

- Make the culture of the civil service changed from reactive to proactive.

- Accountable and open government.

- Cost-effective procurement.

3. Government to Business (G2B), this is to achieve a powerful business development.

- De-regulation and legislative reform

- A national economy with flexibility and competitiveness within the global markets.

- Skilled, IT literate, and flexible citizens for the labor market

G2B could be found in Jordan in the clearing house for cheques, clearing between central bank from one side and the other banks in the economy. The submission of tax assessment by any business establishment to the department of Taxation of the government through the Internet (online).

4. An integrated society, where long distances and borders are not a problem anymore in it, in the contrary, saving time and fast services will be the new trend.

Results of achieving the E-government in this way will be noticed as follows:

- Connect rural and far areas with high-speed Internet access, so all the people can get the same services provided online.

- Citizens will be able to do their payments for many governmental charges from home.

- Overcome some barriers that used to be a problem in the normal government such as disability and gender barriers, even though this point depends on the country or culture, for example, disabled people in most of the developed countries can do their duties by themselves, as everything is ready for them. But in the developing countries it is almost impossible for some disabled people to do most of their governmental procedures by themselves, as there are no facilities to help them. That means e-services will be really effective for disabled people and almost ideal.

- Increase the sense of community.

Increase the involvement in the electoral process in a very democratic and reliable way. This is a very advanced level, that still under study in many developed countries to make sure to implement it away from fraud.

To achieve the previous expectations E-government in Jordan has offered E-government Portal. To deliver informational and directory services related to the Government of Jordan in the first stage. Then in the second phase of the E-government Portal will fully integrate the Portal with the E-government Enterprise Federated Architecture and Shared services, finally enabling transactional E-government services (Transactional Portal). Ultimately, the portal will be a "one stop shop" for user interaction with all Government of Jordan entities.

In 2004, thirteen initiatives were implemented, plus thirty individual projects, that included connecting six ministries to e-mail system and government network, implementing some e-services like income tax filling, and giving training courses to more than 4000 government employees about computer literacy and IT.

Despite this ambitious initiative, it was faced by several obstacles, one of the major obstacles was social awareness and readiness, where most of users (especially citizens) were not informed or trained properly on 
such implementation, which forced the government to stop the implementation process for more reassessment at a later stage.

The E-government strategy report [17], which was done by the MOICT, has addressed many different useful information about the E-government in Jordan, includes the four Pillars of E-government in Jordan (i.e. Institutional framework, Legal framework, ICT infrastructure, and Business), the National E-government vision ("Egovernment in Jordan is dedicated to delivering services to people across society, irrespective of location, economic status, education or ICT ability. With its commitment to a customer-centric approach, E-government will transform government and contribute to the Kingdom's economic and social development), and new strategy of the E-government in Jordan at that time which was covering the years (2007, 2008, and 2009).

\section{E-Government Readiness in Jordan}

E-Readiness is briefly defined as the degree to which a country is prepared to participate in the networked world (McConnell report, 2000 [18]). The United Nations Department of Economic and Social Affair (UNDESA) issued every two years a report measuring the development of E-government of 193 member states by calculating the E-government development Index value (EGDI). It is a composite index includes a: 1) telecommunication connectivity; 2) scope and quality of online services; and 3) human capacity as in Equation (1). Seven E-government surveys have conducted from 2003 until now. The purpose of UN surveys is to achieve better understanding for the status of E-government across the world to governments, the private sectors, and the researchers.

The United Nations E - government development index(EGDI)

$$
=1 / 3 *\left(\text { OSI }_{\text {normalized }}+\text { TII }_{\text {normalized }}+\text { HCI }_{\text {normalized }}\right)
$$

In this study, the researchers used government publications, newspapers, and research papers to collect data and hence analyze the current status of Jordanian E-government. The MOICT worked on a long term initiative to implement E-government. To achieve this, E-government in Jordan has set measurable goals and objectives [17]:

$\checkmark$ Improve service delivery and the quality and speed of government's interaction with citizens and businesses as well as among government entities.

$\checkmark$ Improve responsiveness to customer needs by using new modes of contact to provide public sector information and services.

$\checkmark$ Increase transparency of government by increasing the availability of information and accessibility to services.

$\checkmark$ Save time and money by improving efficiency in government processing, in part through use of common technology standards, policies and a federated architecture, as well as contributing to financial reform within the public sector.

$\checkmark$ Create positive, spin-off effects on Jordanian society through the promotion of ICT skills development within government, businesses and households that will strengthen Jordan's economic competitiveness.

This strategy covered the years 2007, 2008 and 2009 which is good enough at the that time to support King Abdullah II vision which is a very ambitious vision, and efforts are being done to achieve this target, but in real life, and in the researchers point of view, it will take longer time from what is expected, as infrastructure like ICT tools, and skilled people are still not completely ready, as a result this strategy need update during the next years to keep abreast with the technological development.

As a result of the this strategy, the Jordanian E-government achieved the best improvement in 2008 and 2010 [11] as shown in Figure 1, in 2008 Jordan achieved 0.1693 degree in the telecommunication infrastructure index, 0.6054 in the online services index and 0.8677 in the human capital index as you see in Figure 2, the reasons of this improvement are the understanding of the importance of E-government websites and service from the society [19].

But in year 2012, the ranking dropped down 47 positions. It is obvious that the drop in ranking is basically return to the slowness in introducing e-services to the public. The lack of financial allocations for E-government services is negatively affecting the progress in this regard. The lack of necessary funds is also affecting the upgrade of infrastructure required for introducing additional E-government services [20].

In year 2014, Jordan ranked 79 globally in United Nations Report of the 2014, ahead 19 positions. This pro- 


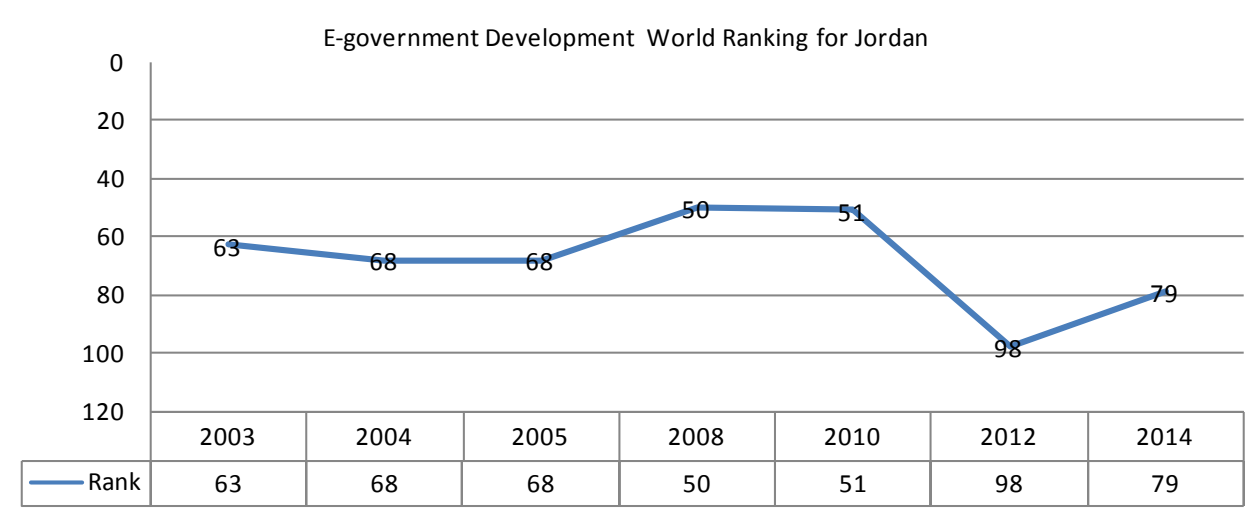

Figure 1. E-government development world ranking for Jordan.

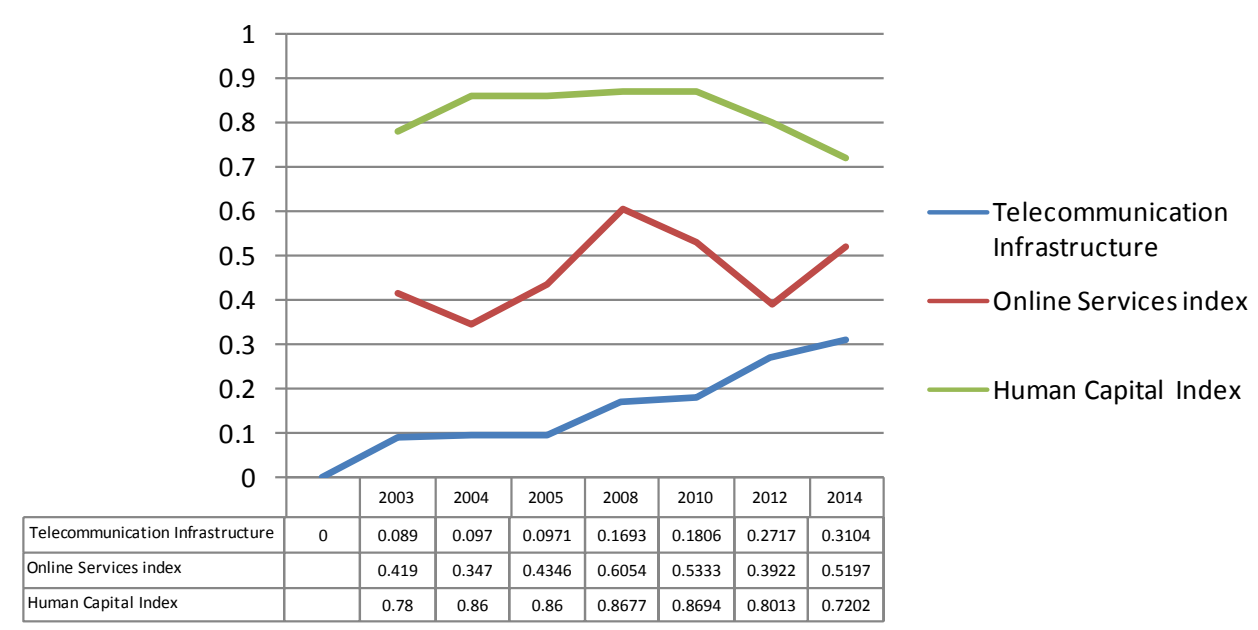

Figure 2. Telecommunication infrastructure, online services, and human capital indices of Jordan.

gress came within the continued efforts of the Ministry of Information and Communication Technology (MOICT) through the E-government program, where the number of electronic services provided through the E-government portal is increased, activate the e-participation and the means of social communication, and start activating the open data on the gate, in addition to the work and cooperation with the most important ministries that represent key sectors such as health, education, environment, finance, labor and social development to improve the quality of services provided to citizens [21]. As you see in Figure 2, Jordan achieved 0.5197 points in the overall index for online services which is higher than the global average which stood at 0.3919 degrees, and achieved 0.3104 in the telecommunication infrastructure index which is less than the global average of 0.3650 degree with small drop. This indicator measures the spread of fixed telephone lines, internet users, personal computers, use of mobile, in year 2008 new indicator added to them which is fixed broad band. In year 2012 the availability of personal computers changed to fixed internet subscriptions and in year 2014 changed to wireless broadband subscriptions. The third indicator, which measures the human capital, Jordan has recorded 0.7202 degree outperforming the global average of 0.6566 degree. This indicator reflects the literacy rate and enrollment in primary and secondary education [22].

In this research, the researchers have adopted trend analysis method to find the trends (positive or negative) in the UN E-government indicators in Jordan. Trend analysis is a special case of regression analysis where the dependent variable is the data to be forecasted and the independent variable is the time. To calculate the trends four to seven year data were needed for telecommunication infrastructure index and three year data for the online services index where the data for the other years isn't available.

As shown in Table 1, Jordan telecommunication infrastructure index has continuously improved during the period (2003-2014) [10] [11] [22], all indicators with positive trend except the main fixed phone lines with negative trend of -1.151 and this is normal due to the spread of use mobile devices. In 2003, the overall telecom- 
Table 1. Telecommunication infrastructure indicators (per 100 persons) — trend analysis.

\begin{tabular}{|c|c|c|c|c|c|c|}
\hline Year & Index & $\begin{array}{c}\text { Estimated } \\
\text { Internet Users }\end{array}$ & $\begin{array}{l}\text { Main Fixed } \\
\text { Phone lines }\end{array}$ & $\begin{array}{c}\text { Mobile } \\
\text { Subscribers }\end{array}$ & $\begin{array}{l}\text { Personal Computers/ } \\
\text { Fixed internet } \\
\text { subscriptions (2012) } \\
\text { /wireless broad } \\
\text { band (2014) }\end{array}$ & $\begin{array}{c}\text { Fixed } \\
\text { Broadband }\end{array}$ \\
\hline 2003 & 0.089 & 4.516 & 12.76 & 16.71 & 3.28 & - \\
\hline 2004 & 0.097 & 5.77 & 12.66 & 22.89 & 3.75 & - \\
\hline 2005 & 0.0971 & 8.100 & 11.36 & 24.19 & 4.500 & - \\
\hline 2008 & 0.1693 & 13.65 & 10.52 & 74.40 & 6.22 & 0.83 \\
\hline 2010 & 0.1806 & 24.46 & 8.46 & 86.60 & 7.20 & 2.09 \\
\hline 2012 & 0.2717 & 38.00 & 7.84 & 106.99 & 4.06 & 3.18 \\
\hline 2014 & 0.3104 & 41.00 & 6.20 & 128.17 & 10.86 & 2.76 \\
\hline Trend & 0.038 & 6.795 & -1.151 & 20.178 & 0.931 & 0.688 \\
\hline
\end{tabular}

munication infrastructure was low as 0.089 but the value increased to 0.3104 in 2014 . The trend analysis showed as that Jordan telecommunication infrastructure index is improving every year with positive trend value of 0.038 .

The improvement in global ranking for Jordan in the year 2014 is basically return to the E-services to the public which is one of the main goals of the new strategy of E-government in Jordan as will be discussed in details in another section. The local Government of Amman, the capital of Jordan, has launched an SMS services portal [21] aimed at increasing the channels of communications between citizens and governments. It is now recognized as the most prevalent communication tool with all segments of the Jordanian community, helping in enhancing the quality and efficiency of governmental services. It provides citizens with two types of services: 1) push messages by governmental institutions and departments such as reminders and awareness campaigns; and 2) pull messages that are sent by citizens as an SMS inquiry and are automatically responded to by the relevant governmental department [22].

Jordan online service index has continuously improved during the period (2010-2014), all stages with positive trend as shown in Table 2. Best trend in stage 1 "Emerging information services" where Jordanian government websites provide information on public policy, governance, laws, regulations, relevant documentation and types of government services provided. They have links to ministries, departments and other branches of government. Citizens are easily able to obtain information on what is new in the national government and ministries and can follow links to archived information. Good progress on stage 2 "Enhanced information services, until now government websites deliver enhanced one-way e-communication between government and citizen, such as downloadable some forms for government services and applications. Not bad progress in stage 3 "Transaction services”, No engagement between government websites in two-way communication with the citizens, including requesting and receiving inputs on government policies, programs, regulations, etc. Good progress in stage 4 is "Connected services" which means that government websites have changed the way governments communicate with their citizens. They are proactive in requesting information and opinions from the citizens using Web 2.0 and other interactive tools. E-services and e-solutions cut across the departments and ministries in a seamless manner. Information, data and knowledge is transferred from government agencies through integrated applications. Governments have moved from a government-centric to a citizen-centric approach, where e-services are targeted to citizens through life cycle events and segmented groups to provide tailor-made services [20]. Actually Now Jordan at the end of stage 2 and MOICT issued a new strategy for E-government which will be discussed in details in another section.

\section{Challenges and Opportunities Affecting the Success of E-Government in Jordan}

Nowadays governments around the world are racing to implement the E-government concept in their countries, but some of them have suffered failure in adopting E-government concept [23]. According to Heeks (2004), 
Table 2. Online services indicators-trend analysis.

\begin{tabular}{ccccc}
\hline Year & $\begin{array}{c}\text { Emerging information } \\
\text { services (stage 1) }\end{array}$ & $\begin{array}{c}\text { Enhanced information } \\
\text { services (stage 2) }\end{array}$ & $\begin{array}{c}\text { Transactional services } \\
\text { (stage 3) }\end{array}$ & $\begin{array}{c}\text { Connected services } \\
\text { (stage 4) }\end{array}$ \\
\hline $\mathbf{2 0 1 0}$ & 0.5 & 0.44 & 0.57 & 0.17 \\
$\mathbf{2 0 1 2}$ & 0.83 & 0.48 & 0.31 & 0.20 \\
$\mathbf{2 0 1 4}$ & 0.91 & 0.41 & 0.21 & 0.50 \\
Trend & 0.298 & 0.123333 & 0.042333 & 0.162 \\
\hline
\end{tabular}

most of E-government project in developing countries have failed, 35\% of E-government project are total failures, $50 \%$ are partial failures and only $15 \%$ are success [24].

The most challenges that are expected to be faced during the implementation of an E-government program have been summarized from the E-government handbook of developing countries [25], presented in Table 3. A set of recommendations has been provided to assist in overcoming the challenges and obstacles in the road for developing a successful E-government.

Most researches on E-government have focused on developed countries. Of those that are focused on E-government in developing countries, a few have highlighted several issues that need to be faced [26]-[30].

Jordan is one of such developing countries, M. Al-Shboul et al. (2014) [31] declared in their research that key factors and challenges affect E-government services adoption in Jordan can roughly categorized under four heading; political factors, social factors, organizational factors, and technological factors [32] [33].

- Political factors: Implementing E-government projects needs huge financial investments. As a result of the lack of available financial resources top leadership gradually lose their enthusiasm to implement E-government.

- Social factors: People who don't have internet access will be unable to advantage from online services which form an important barrier to E-government.

- Organizational factors: Successful implementation of E-government should involve restructuring the existing organizational model, roles, responsibilities, training, and employee's needs [34], thus lack of employee training will be a considerable challenge.

- Technological factors: Required information technology standards to achieve citizens' needs and to pass up any hardware and system barriers that might delay the implementation of E-government. One of the most significant technological challenges is computer security. Stability of E-government services is important for availability and service delivery as well as for Building citizen confidences. Moreover privacy is a core challenge to E-government implementation and acceptance, it concern sharing information among participating government agencies and exposing or mishandling private information.

Moreover, they expose other additional factors affect E-government adoption, implementation, and usage in the Hashemite kingdom of Jordan: legislation and legal framework; human resistance to change, security and privacy issues; culture issues; trust in E-government; usefulness and complexity issues; website design issues; access and IT skill issues; operational cost; organizational issues; technical infrastructure; usability, availability, and accessibility issues. These challenges are relatively similar to challenges cited in [35].

This study suggested some recommendations based on the knowledge gained from the research:

- Transforming into E-government services should not be treated as only a computerization of governmental operation but also as a restructuring process.

- Using the existing academic institutions to enhance peoples' awareness by adopting training courses on E-government knowledge.

- Collaboration with the private sector, which can be helpful in cost-sharing, project and technology management expertise.

- Controlling and getting over the resistance to change by clarifying the transformation aims to employee.

\section{New Strategy of E-Government in Jordan Covering the Years $(2014,2015,2016)$} [36]

The MOICT presented the new strategy of E-government in Jordan covering the years (2014, 2015, and 2016), 
Table 3. Challenges to be faced during the implementation of an E-government and recommendations to overcome these challenges.

Challenges
1. Infrastructure Development
All countries implementing E-government have struggled
to develop a basic infrastructure to take advantage of new
technologies and communications tools. Many developing
countries, even if possessing the will, do not have the
infrastructure necessary to immediately deploy
E-government services
throughout their territory

Recommendations

- Develop projects that are compatible with the nation's telecom infrastructure.

- Use public access kiosks and mobile centers if telecommunication density is low.

- Introduce telecom competition and lift regulations on wireless and other digital technologies to accelerate their deployment.

- Build on the microenterprise model to bring connectivity to underserved areas and ensure sustainability.

- Consider the government's current use of technology and learn from past successes and failures.

- Establish an action framework at the beginning of the process to allow for a rational and coordinated investment effort down the road.

\section{Law and Public Policy}

The application of Information Technology and Communication (ICT) to government may encounter legal or policy barriers. Legislatures must ensure that laws are updated to recognize electronic documents and transactions. Policymakers implementing E-government must consider the impact of law and public policy.

\section{Digital Divide}

The digital divide is the gap between people who have access to the Internet and those who do not. Those without access cannot learn essential computer skills, cannot access • information that can provide economic opportunities, and • cannot share in the benefits of E-government.

\section{E-Literacy}

E-Literacy refers to marginalized groups who are unable to make use of information and communication technologies because they are not computer literate. With the digital revolution there is a very real danger that the world will be • divided into the "information rich" and the "information poor". E-government has the potential of either equalizing access to government and its services or increasing the barriers to participation.

\section{Accessibility}

Governments must serve all members of society irrespective of their physical capabilities (disabled people: those who are blind, deaf or otherwise handicapped). Online services will have to be designed with appropriate interfaces.

6. Trust

To be successful, E-government projects must build trust within agencies, between agencies, across governments, and with businesses, NGOs and citizens

\section{Privacy}

Governments must be responsible custodians Of the enormous amounts of personal information they hold. Governments collect vast quantities of data on their citizens through everyday transactions. Protecting the privacy of citizens' personal information stored on these databases while making effective use of the information contained in them is a vitally important issue.
- Consult with stakeholders to assess how existing laws may impede the desired results.

- Give legal status to online publication of government information.

- Clarify laws and regulations to allow electronic filings with government agencies.

- $\quad$ Reform processes by simplifying regulations and procedures.

- $\quad$ Provide communal access through village computer centers or kiosks.

- Combine access with training.

Provide incentives to the private sector to donate equipment and training. Emphasize local language and content tailored to different communities. Use for-profit entrepreneurs to build and sustain access points in small communities

- Ensure that content is in local languages and that interfaces are easy to use.

Develop applications that use speech or pictures in addition to, or instead of, written text.

- Include an educational component in E-government projects.

Provide aides at access points who can train citizens in basic computer skills.

Create programs that include traditional media, like radio programs or newspaper columns, where citizens can learn about E-government.

- Special attention should be given to groups difficult to integrate (women, elderly, immigrants).

- From the outset, design applications that accommodate the disabled, such as an audio option for the blind.

- Establish as a legal requirement that the government must adopt technology to assist the disabled.

- $\quad$ Set performance criteria and measure progress

- Map key internal and external partners and build a strategy to keep open lines of communications.

- Start with short-term projects that yield early results. This helps build trust and could help point to areas for larger scale ventures.

- Strong leadership can help build confidence in programs.

- Educate and train government officials on the importance of privacy.

- Design applications that integrate privacy protections.

- Follow "fair information practices". Minimize the collection and retention of personal information.

- Limit access to personally identifiable information-do not automatically allow employees to tap into databases of personally identifiable information. 


\section{Continued}

\section{Security}

Security is costly, but must be addressed in the design phase, as security breaches can shatter public trust in E-government. Trust is a vitally important component of E-government projects. Without trust, citizens who may already be leery of using technology may avoid and even shun the use of online services that ask for detailed personal information.
9. Transparency

Citizens too rarely understand how government decisions are made. This lack of transparency prevents the public from actively participating in government and from raising questions or protesting unfair or ill-advised decisions. A lack of transparency can conceal official graft or favoritism.

10. Interoperability

Putting incompatible record formats online neither simplifies nor reduces the workload imposed on people and government officials. Reliable E-government requires a comprehensive overhaul of legacy systems.

\section{Records Management}

Better information management can help officials identify barriers to more efficient government. An information management framework is necessary to make sense of available data. Without this framework, policy makers could not derive useful analysis quickly enough to react to social and economic developments.

12. Permanent availability and preservation Historical documentation is of special importance for governments. ICT not only allows for quick and cheap dissemination of data, but also for its compact and convenient storage.

13. Education and Marketing

E-government services are only useful if people know about them. Education and outreach programs will be needed.

14. Public/Private competition/collaboration Answering the question of where government controls end and the private sector takes over in E-government efforts.

15. Workforce issues

Human resources must be structured and managed with E-government goals in mind. A well-trained and motivated workforce is critical to E-government success.
- Designate a senior official responsible for computer security.

- Continually assess systems to make sure that security precautions are being implemented.

- Backup information regularly and store backups in a separate location.

- When it comes to personal information, keep information collection to a minimum and do not disclose personal information without express prior consent.

- $\quad$ Provide ongoing training to employees on computer security.

- Evaluate performance of system managers in adhering to sound security practices.

- Post online rules, regulations and requirements for

- government services (such as requirements for obtaining

- A license) to minimize subjective actions by officials.

Highly-placed public officials can expedite transparency and accountability efforts by making their offices positive examples of openness.

- When putting services online, give citizens the ability to track the status of their applications.

- Train civil servants and provide incentives to reform.

- Integrate transparency and process reform to simplify regulations and procedures.

- Map and assess existing record systems.

- Identify and reform regulatory schemes that make interaction with the government onerous.

- Use common standards throughout the government to shorten development time and ensure compatibility.

- Adopt a common IT infrastructure for the government.

- Encourage data sharing and cooperation between government departments.

- Streamline offline record keeping processes to make the transformation to online publication easier.

- Creation and standardization of meta-data is critical for conducting successful data searches across institutions and networks.

- Design applications according to need.

- Consider relevance, usability, language compatibility and affordability.

- Encourage cooperation between departments and with the private sector in collecting, storing and utilizing data but proceed continuously with personally identifiable information.

- Develop publicity and training campaigns that will engage the public about E-government initiatives.

- Conduct research to ensure that online services respond to actual needs and that the implementation suits the target audience.

- $\quad$ Forge multi-sector partnerships.

- Review and reassess laws and policies that impede public/private cooperation.

- Ensure that agreements with contractors and partners are equitable and can be reviewed and revised over time.

- Seek assistance and involvement from organizations that already have experience in providing services and information using the same or similar technologies

- Articulate a timeline for implementation in a step by-step manner so the reforms will not seem overwhelming to the bureaucracy.

- Hold regular meetings between E-government policy leaders and the affected workforce so employees are active participants in the process.

- Create incentives by rewarding individuals and agencies that apply the reforms rapidly. 


\section{Continued}

16. Cost structures

While planning and budgeting in a changing climate is difficult, governments should seek to invest in sustainable programs that can produce savings.

17. Benchmarking

Governments must regularly evaluate the progress and effectiveness of their E-government investments to determine whether stated goals and objectives are being met on schedule
- Avoid advertising-based or fee-based services. They have generally not been sustainable.

- Articulate functionalities clearly and try not to add details that will push budgets into deficit.

- Develop projects that are achievable with resources available.

- Consider the government's current use of technology and study past successes and failures.

- Designate an officer or organizing body that will oversee cost.

- Create measurable goals during early planning stages.

- Designate an office to oversee E-government implementation.

- Make sure the office is sufficiently funded and is recognized by all relevant agencies and departments.

- Conduct regular audits to ensure progress is being made to achieve stated goals.

- Review benchmarks regularly to ensure that accurate measures are appropriate for rapidly changing technology.

- Create a data collection system to support program operations and "before and after" surveys of knowledge, skills, and applications among participating organizations to assess program impact.

- A common IT infrastructure and architecture standard is key to ensuring that ongoing development takes place in a coherent and integrated way.

- Advanced planning of common IT infrastructure standards result in shortened development time and system compatibility.

- Quantitative measures can be as beneficial as qualitative ones.

which emphasize on encouraging and motivating government entities to deliver high-quality customer-centric and performance-driven services to E-government beneficiaries while transforming from traditional service delivery to more effective and efficient service providers to their beneficiaries (Citizens, Residents, Visitors, Businesses, Government Entities and Government Employees). In UN report 2012, the participation of all in E-government is imperative to promote economic and social empowerment through ICT for all citizens including vulnerable groups pre-identified by the UN as the Poor, illiterate, blind, old, young, immigrants and women.

The new strategy presents priority of E-government initiatives, tools and projects (as shown in Figure 3). The Jordan E-government will launch three main initiatives during the period of this strategy that aim to provide incentives for government entities to pay more efforts toward e-Transformation to better serve their beneficiaries and improve the overall progress of Jordan achievements compared with regional and global countries.

1) E-government Award: The goal of it is to encourage entities, individuals and organizations succeed and develop their creativity in the field of E-government in information and communication technology to promote e-community.

2) Measuring E-government E-Transformation "MADA": The goals of this measurement determining the challenges facing government entities in the process of e-Transformation, enable decision makers and E-government Program to outline corrective policies that correspond to such challenges, and motivating government entities to give more priority to become e-Transformation leaders.

3) Business Development "DALEEL": The goal is promote E-government consulting services toward business development and employ accumulative knowledge and experience in enabling government entities to achieve e-Transformation.

The four stages of e-transformation are evolving around the maturity of service delivery (emerging, enhanced, transactional, and connected). Government of Jordan is aiming to achieve the transactional stage by end of this strategy. Jordan is currently is in the late enhanced stage given that government of Jordan offer more sources of information through the National Government Portal, the National Contact Center (NCC), the National Mobile Portal and National SMS Gateway.

\section{Conclusions}

Government is a dynamic mixture of goals, structures and functions. After the technological revolution the government is extended to produce E-government. Many researches discussed and worked on E-government in developing and developed countries. Jordan is one of developing countries that has embarked on the E-government initiative and is expected to take several years to complete and E-government in Jordan is not a policy standing 


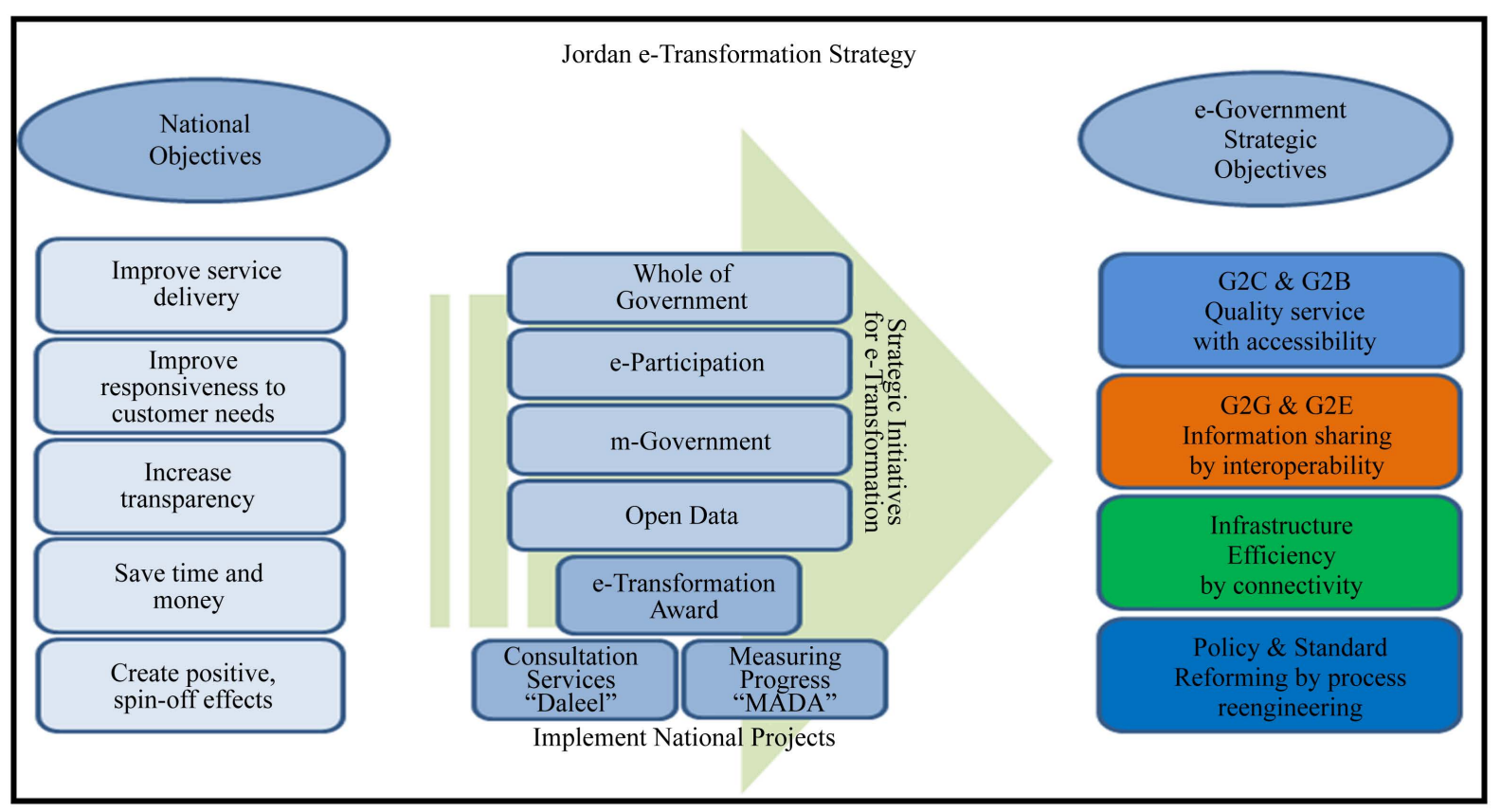

Figure 3. New strategy of E-government in Jordan for the years (2014, 2015, and 2016).

in isolation; it is an integral element of the Kingdom's National Agenda.

This research provided an overview of the past, current, and future status of E-government in Jordan by taking all aspects and sides of E-government program in Jordan which can help in the development of proposals, plans and strategies to improve the level of E-government in Jordan and give trend analysis to get the Jordan trends (positive or negative) in the UN E-government indicators.

\section{References}

[1] Pardo, T. (2000) Realizing the Promise of Digital Government: It’s More than Building a Web Site. Center of Technology in Government, University of Albany.

[2] Al-Mashari, M. (2007) A Benchmarking Study of Experiences with Electronic Government. Benchmarking: An International Journal, 14, 172-185. http://dx.doi.org/10.1108/14635770710740378

[3] Sprecher, M.H. (2000) Racing to E-government: Using the Internet for Citizen Service Delivery. Government Finance Review, 16, 21-22.

[4] Schware, R. and Deane, A. (2003) Deploying E-Government Programs: The Strategic Importance of "I” before "E". Info, 5, 10-19. http://dx.doi.org/10.1108/14636690310495193

[5] Tambouris, E., Gorilas, S. and Boukis, G. (2001) Investigation of Electronic Government. 8th Panhellenic Conference on Informatics, 8-10 November 2001, Nicosia.

[6] Fang, Z.Y. (2002) E-Government in Digital Era: Concept, Practice and Development. International Journal of the Computer, the Internet and Management, 10, 1-22.

[7] Carter, L. and Belanger, F. (2004) Citizen Adoption of Electronic Government Initiatives. HICSS 2004—Proceedings of the 37th Annual Hawaii International Conference on System Sciences, Hawaii, 5-8 January 2004. http://dx.doi.org/10.1109/HICSS.2004.1265306

[8] Wang, Y.S. and Liao, Y.W. (2008) Assessing eGovernment Systems Success: A Validation of the DeLone and McLean Model of Information Systems Success. Government Information Quarterly, 25, 717-733. http://dx.doi.org/10.1016/j.giq.2007.06.002

[9] Bose, R. (2004) Information Technologies for Education \& Training in E-Government. International Conference on Information Technology: Coding and Computing, 5-7 April 2004, 203-207.

[10] United Nations (2005) Global E-Government Readiness Report 2005-from E-Government to E-Inclusion. United Nations Division for Public Administration and Development Management. http://unpan1.un.org/intradoc/groups/public/documents/un/unpan021888.pdf 
[11] United Nations (2008) Global E-Government Readiness Report 2008—From E-Government to Connected Governance. United Nations Division for Public Administration and Development Management. http://unpan1.un.org/intradoc/groups/public/documents/un/unpan028607.pdf

[12] Abu-Samaha, A. and Samad, Y. (2007) Challenges to the Jordanian Electronic Government Initiative. Journal of Business Systems, Governance and Ethics, 2, 101-109.

[13] AbuShanab, E. and Pearson, J. (2007) Internet Banking in Jordan: The Unified Theory of Acceptance and Use of Technology (UTAUT) Perspective. Journal of Systems and Information Technology, 9, 78-97. http://dx.doi.org/10.1108/13287260710817700

[14] Elsheikh, Y., Cullen, A. and Hobbs, D. (2008) E-Government in Jordan: Challenges and Opportunities. Transforming Government: People, Process and Policy, 2, 83-103.

[15] Mohammad, H., Almarabeh, T. and Abu Ali, A. (2009) E-Government in Jordan. European Journal of Scientific Research, 35, 188-197.

[16] Blakemore, M. and Dutton, R. (2003) E-Government, E-Society and Jordan: Strategy, Theory, Practice, and Assessment. http://dx.doi.org/10.5210/fm.v8i11.1095

[17] The Hashemite Kingdom of Jordan, Ministry of Information and Communications Technology (2006). http://www.moict.gov.jo/HOme.aspx

[18] McConnell International Report (2000) Risk E-Business: Seizing the Opportunity of Global E-Readiness. http://www.mcconnellinternational.com/index.php?option=com content\&view=article\&id=10\&Itemid=6

[19] Almarabeh, T. and Abu Ali, A. (2010) A General Framework for E-Government: Definition Maturity Challenges, Opportunities, and Success. European Journal of Scientific Research, 39, $29-42$.

[20] Almarabeh, T. and Adwan, O. (2013) A Detailed Study of E-Government Readiness in Jordan. International Journal of Computer Science Issues, 10, 88-96.

[21] Greater Amman Municipality, Jordan. http://www.ammancity.gov.jo/en/gam/index.asp

[22] United Nations (2014) Global E-Government Readiness Report 2014-E-Government for the Future We Want. United Nations Division for Public Administration and Development Management. http://unpan3.un.org/egovkb/Reports/UN-E-Government-Survey-2014

[23] Gagne, J.C.D. and Walters, K. (2009) Online Teaching Experience: A Qualitative Meta Synthesis (QMS). The MERLOT Journal of Online Learning and Teaching, 5, 577-589.

[24] Heeks, R. (2004) Causes of E-Government Success and Failure: Factor Model. Institute for Development Policy and Management, University of Manchester, Manchester.

[25] The E-Government Handbook for Developing Countries, Center of Democracy and Technology, 2002.

[26] Wagner, C., Cheung, K., Lee, F. and Ip, R. (2003) Enhancing E-Government in Developing Countries: Managing Knowledge through Virtual Communities. Electronic Journal on Information Systems in Developing Countries, 14, 120. www.seu.ac.lk/cedpl/research\%20and\%20thesis/89-89-1-PB.pdf

[27] Heeks, R. (2002) E-Government in Africa: Promise and Practice. Information Polity, 7, 97-114.

[28] Reffat, R. (2003) Developing a Successful E-Government. Proceedings of the Symposium on E-Government: Opportunities and Challenge, Muscat Municipality, 10-12 May 2003, IV1-IV13.

[29] Ndou, V. (2004) E-Government for Developing Countries: Opportunities and Challenges. Electronic Journal on Information Systems in Developing Countries, 18, 1-24.

[30] Bose, R. (2004) Information Technologies for Education \& Training in E-Government. Proceedings of the ITCC 2004 International Conference on Information Technology: Coding and Computing, Las Vegas, $5-7$ April 2004, 203-207.

[31] Al-Shboul, M., Rababah, O., Ghnemat, R. and Al-Saqqa, S. (2014) Challenges and Factors Affecting the Implementation of E-Government in Jordan. Journal of Software Engineering and Applications, 7, 1111-1127. http://dx.doi.org/10.4236/jsea.2014.713098

[32] Weerakkody, V., El-Haddadeh, R. and Al-Shafi, S. (2011) Exploring the Complexities of E-Government Implementation and Diffusion in a Developing Country: Some Lessons from the State of Qatar. Journal of Enterprise Information Management, 24, 172-196. http://dx.doi.org/10.1108/17410391111106293

[33] Bonham, G., Seifert, J. and Thorson, S. (2001) The Transformational Potential of E-Government: The Role of Political Leadership. Proceedings of the 4th Pan European International Relations Conference, Canterbury, 6-10 September 2001, 1-9.

[34] Ebrahim, Z. and Irani, Z. (2005) E-Government Adoption: Architecture and Barriers. Business Process Management Journal, 11, 589-611. http://dx.doi.org/10.1108/14637150510619902

[35] Al-Shafi, S. (2009) Factors Affecting E-Government Implementation and Adoption in the State of Qatar. Ph.D. Thesis, 
Brunel University, London.

[36] Jordan E-Government (2013) E-Government Strategy 2014-2016.

http://inform.gov.jo/Portals/0/Report\%20PDFs/7.\%20Role\%20\&\%20Performance\%20of\%20Government/i.\%20Public \%20Sector\%20Reform\%20\&\%20Development/2014-2016\%20MOICT-E-government\%20Strategy-Draft.pdf 